\title{
Studi Kemampuan Penyerapan Panas pada Atap Rumah Seng Berwarna Terhadap Intensitas Matahari dalam Mengatasi Global Warming
}

\author{
Nazaruddin $^{1^{*}}$, Teuku Zulfadli ${ }^{2}$ Andi Mulkan ${ }^{3}$ iD \\ 1,3 Department of Mechanical Engineering, Iskandarmuda University, Aceh, Indonesia \\ ${ }^{2}$ Politeknik Negeri Lhokseumawe \\ *Corresponding author: nazarsimpo8@gmail.com
}

\begin{abstract}
Temperature lingkungan meningkat signifikan mencapai 33 derajat Celcius seperti yang dirasakan oleh masyarakat salah satunya di Daerah Aceh memicu terjadinya Pemanasan Global (Global Warming. Akibat kenaikan temperatur di daerah Aceh menyebabkan banyak bangunan dan rumah tempat tinggal menjadi tidak nyaman terutama pada saat siang hari karena sebagian besar bangunan rumah beratapkan seng. Hal ini akan menyebabkan suhu di dalam rumah dan udara sekelilingnya meningkat. Oleh karena itu perlu dilakukan penelitian tentang studi penyerapan panas pada atap rumah seng yang bewarna. Metode penelitian ini dengan menghitung penyerapan panas (intensitas matahari) pada seng yang telah dilapisi beberapa macam warna seperti putih, merah, biru, kuning dan hitam. Tujuan dari penelitian ini untuk mengetahui warna yang paling sedikit terhadap penyerapan panas terhadap intensitas matahari. Temperatur ruang tertinggi pada seng berlapis warna hitam $49,2{ }^{\circ} \mathrm{C}$ dan yang terendah pada warna putih $40,9{ }^{\circ} \mathrm{C}$ dari pengamatan suhu lingkungan terdapat temperatur paling tinggi pada jam 12.00. temperature ruangan terjadi peningkatan temperature tertinggi pada pukul 12.00 pada seng berwarna hitam. Ditribusi termperatur ruangan dapat dirata-ratakn yang warna kuning $46,0{ }^{\circ} \mathrm{C}$, warna hitam $49,2{ }^{\circ} \mathrm{C}$, , warna biru $45,5^{\circ} \mathrm{C}$ dan seng warna putih $40,9^{\circ} \mathrm{C}$. Panas yang diserap didalam ruangan sebesar 47,9 joule, maka dari rata keseluruan pengujian dapat digambarkan temperature ruang sebesar 45,6 dan temperature seng $53,8^{\circ} \mathrm{C}$ dari perbedaan temperature tertinggi pada jam 12.00 wib temperatur ruangan dan pukul 13.00 wib Terjadi penyerapan tertinggi pada temperature seng.
\end{abstract}

Keywords: Atap Seng, Penyerapan Panas, Panas Radiasi, Temperature, Kenyamanan Termal

\section{Abstract}

The environmental temperature has increased significantly reaching $33 \mathrm{oC}$ as felt by the community, one of which is in the Aceh region which triggers Global Warming. As a result of the increase in temperature in the Aceh area, many buildings and houses become uncomfortable especially during the daytime because most house with zinc roof. This will cause the temperature in the house and the air around it to increase. Therefore, it is necessary to do research on the study of heat absorption on colored zinc roofs. This research method is to calculate the heat absorption (sun intensity) in zinc that has been coated with several kinds of colors such as white, red, blue, yellow and black. The purpose of this study was to determine the color that has the least amount of heat absorption to the sun's intensity. The highest room temperature on zinc-coated black is $49.2^{\circ} \mathrm{C}$ and the lowest is in white. $40.9^{\circ} \mathrm{C}$ from the pen. In the environmental temperature observation, there is the highest temperature at 12.00. Room temperature increased the highest temperature at 12.00 on black zinc. The distribution of room temperature can be averaged with a yellow color of $46.0^{\circ} \mathrm{C}$, a black color of $49.2^{\circ} \mathrm{C}$, a blue of $45.5^{\circ} \mathrm{C}$ and a white zinc of $40.9 \mathrm{oC}$. The heat absorbed in the room is 47.9 joules, so from the overall average of the test it can be described that the room temperature is 45.6 and the zinc temperature is $53.8 \mathrm{oC}$ from the highest temperature difference at $12.00 \mathrm{WIB}$, room temperature and $13.00 \mathrm{WIB}$ the highest absorption occurs at zinc temperature.

Keywords: Zinc Roof, Heat Absorption, Radiation Heat, Temperature, Thermal Comfort

\section{Introduction}

Pemanasan global adalah kejadian meningkatnya temperatur rata-rata atmosfer, laut dan daratan Bumi (Sarkawi, 2011; Vivi Triana, 2008). Pemanasan global adalah peningkatan gas rumah kaca di atmosfer yang disebabkan oleh kegiatan umat manusia yang meningkatkan

\begin{tabular}{|c|c|c|}
\hline \multicolumn{2}{|c|}{ History: } & \multirow{2}{*}{$\begin{array}{l}\text { Publisher: Undiksha Press } \\
\text { Licensed: This work is licensed under }\end{array}$} \\
\hline \multicolumn{2}{|c|}{ Received $\quad$ : 070 July 2020} & \\
\hline \multicolumn{2}{|c|}{ a Creative Commons Attribution 3.0 License } & \multirow{3}{*}{ (c) (i) (2) } \\
\hline Accepted & : 17 Sepember 2020 & \\
\hline \multicolumn{2}{|r|}{ : 30 October 2020} & \\
\hline
\end{tabular}


efek rumah kaca (Cahyono, 2015). Pemanasan global merupakan fenomena global yang disebabkan oleh aktivitas manusia di seluruh dunia, pertambahan populasi penduduk, serta pertumbuhan teknologi dan industry (Idayati, 2007). Salah satu provinsi yang mempunyai tingkat intensitas matahari yang tinggi. Provinsi Aceh yang terletak di garis Khatulistiwa sehingga memiliki temperatur yang tinggi sepanjang tahun (Machzumy, 2018). Provinsi yang mengalami pemanasan global.

Kondisi ini juga dipengaruhi oleh pemanasan global yang disebabkan oleh jumlah transportasi, hasil pembakaran dari mesin pembangkit listrik, makin berkurangnya jumlah tanaman kota sehingga temperatur yang terus meningkat. Hal ini juga ditambah dengan jumlah rumah di Indonesia yang sebagian besar menggunakan atap berbahan seng. Ketika sinar matahari memancarkan radiasi maka seng akan menyerap panasnya dan mengeluarkan radiasi ke arah sekitarnya dalam bentuk gelombang panjang, karena itu seng disebut sebagai penghantar panas yang baik dan ini menyebabkan ketidaknyamanan penghuninya (Kaamin et al., 2013). Hal ini akan menyebabkan suhu di dalam rumah dan udara sekelilingnya meningkat. Warna atap dengan bahan seng sangat mempengaruhi penyerapan panas matahari. Untuk menghambat pengantaran panas matahari langsung pada atap seng dilakukan lapisan warna atap untuk mencegah radiasi matahari terhadap seng. Selain itu pengaruh kawasan yang memiliki kepadatan bangunan yang tinggi biasanya suhu udaranya sangat tinggi, karena elemen bangunan yang banyak menyerap sinar matahari secara langsung, sedangkan kawasan yang kepadatan bangunan tidak tinggi biasa menghasilkan suhu udara yang rendah karena sinar matahari yang di pantulkan pada elemen bangunan sangat sedikit (Iek et al., 2014)

Warna yang berbeda akan mempengaruhi daya serap terhadap intensitas cahaya. Dimana warna yang terang akan memiliki daya serap yang lebih rendah sedangkan warna yang gelap akan mempunyai daya serap yang lebih besar, hal ini karena pengaruhi oleh perbedaan cahaya dalam bentuk gelombang elektromagnetik yang di serap dan di pantulkan oleh masing-masing warna (Abdul et al., 2019). Setiap warna cahaya memiliki panjang gelombang yang berbeda, serta memiliki kemampuan penetrasi dan daya serap yang berbeda (Rahayu et al., 2011). Pendapat ini didukung hasil penelitian Fajar \& Rohmah, (2019) hasil eksperimen juga menunjukkan bahwa warna berpengaruh terhadap peningkatan suhu pada air akibat radiasi. Warna hitam paling signifikan karena sifat warna hitam ialah menyerap panas secara sempurna.

Pengaruh warna seng terhadap kenyamanan rumah adalah faktor harus diperhatikan. Tujuan dan Sasaran adalah untuk menentukan besar penyerapan panas pada seng atap rumah yang telah dilapisi beberapa warna yaitu putih, merah, biru, kuning dan hitam. Hasil akhir penelitian ini adalah menentukan seng dengan warna yang dapat menyerap lebih sedikit intensitas matahari. Sasaran dari penelitian ini adalah untuk mengurangi pemanasan global dan untuk menciptakan kenyamanan rumah dengan memakai seng warna yang dapat menyerap panas lebih rendah di bandingkan dengan warna yang lain. Hasil dari penelitian ini juga untuk peningkatan publikasi peneliti dalam karya tulis ilmiah nasional terakreditasi, prosiding internasional dan jurnal internasional. Urgensi Penelitian Penelitian ini sangat penting dan perlu dilakukan agar masyarakat dapat mendisain rumah dengan tingkat kenyamanan yang tinggi dengan memakai seng warna yang sesuai. Pemilihan warna seng bukan hanya untuk keindahan tetapi juga untuk mengurangi pemanasan global di dalam rumah dan lingkungan sekitar. Dengan adanya Program PDP ini diharapkan dapat mengurangi dampak pemanasan global dengan cara memilih dan memakai atap seng dengan warna yang paling sesuai. 


\section{Materials and Methods}

Penelitian dilakukan di Laboratorium lapangan Teknik Unida Banda Aceh pada Tanggal 25 September 2020 sampai dengan Tanggal 1 Oktober 2020. Data yang dikumpulkan meliputi data temperature ruangan, temperature seng dan temperature lingkungan. Gambar 1 distribusi temperature dari matahari kedalam ruangan dengan dilapisi plastik warna putih dan dipasang alat thermometer untuk mengukur temperature ruangan dan temperature seng.Alat yang digunakan untuk mengukur temperature pada penelitian ini adalah Termometer digital.

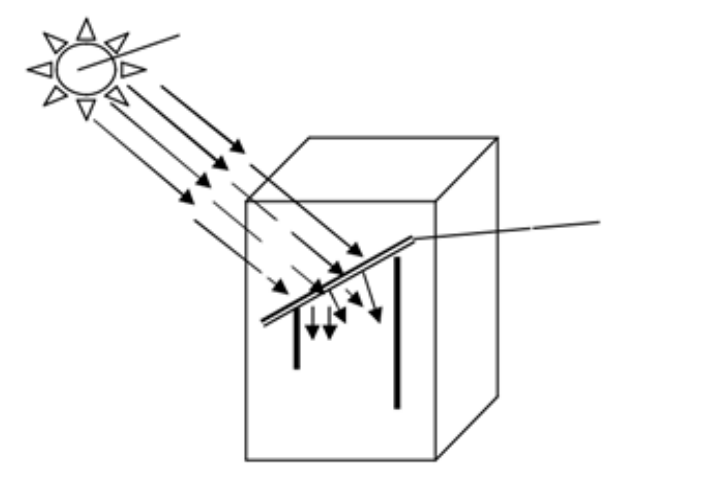

Gamabar 1. Sistim Pengujian dan Distribusi Panas pada Seng

Gambar 1 memperlihatkan peralatan pengujian seng berwarna yang berbentuk kotak persegi dibawah yang dibuat dengan menggunakan rangka kayu dengan ukuran $150 \mathrm{~cm}$ x 150 $\mathrm{cm} \times 250 \mathrm{~cm}$, untuk meminimalkan pengaruh angin dan pengaruh sifat reservoir panas asmosfir bumi maka seluruh ruangan dipasang dengan plastik bening dengan ketebalan $0,25 \mathrm{~mm}$. Pengukuran temperatur kelembaban dan intensitas matahari dilakukan dengan menggunakan thermometer digital dan lux meter, untuk ketebalan seng 0,25 mm. Data yang dikumpulkan kemudian dianalisis dengan menggunakan distribusi frekuensi untuk melihat kecenderungan temperatur yang telah diukur sesuai masa pengamatan. Temperatur seng, temperature ruangan dan temperature lingkungan dirata-ratakan menurut waktu pengamatan sehingga dapat diketahui waktu dan warna seng yang paling sedikit menyerap panas serta yang paling tinggi menyerap panas.

\section{Results and Discussion}

Hasil pengamatan diperoleh data temperature ruang, temperature seng dan temperature lingkungan. Temperatur diukur dengan kemiringan seng $40^{\circ}$ dan dilakukan di beberapa titik pemasang alat thermometer yang dianggap mewakili pada sistem pengujian. Waktu ukur temperature dimulai dari pukul 10.00 WIB sampai dengan 16.00 WIB. Temperatur dilakukan pengukuran pada intensitas cahaya matahari pada kondisi cerah Pengukuran temperatur dan intensitas cahaya dilakukan dalam kondisi udara cerah dan dilakukan setiap 1 jam dimulai dari jam 9.00 wib ke jam 10.00 wib sampai dengan pada pukul jam 16.00wib. Hasil penelitian akan ditampilkan sebagai berikut.

Hasil pengamatan pada temperature yang diukur disajikan pada gambar berikut. 


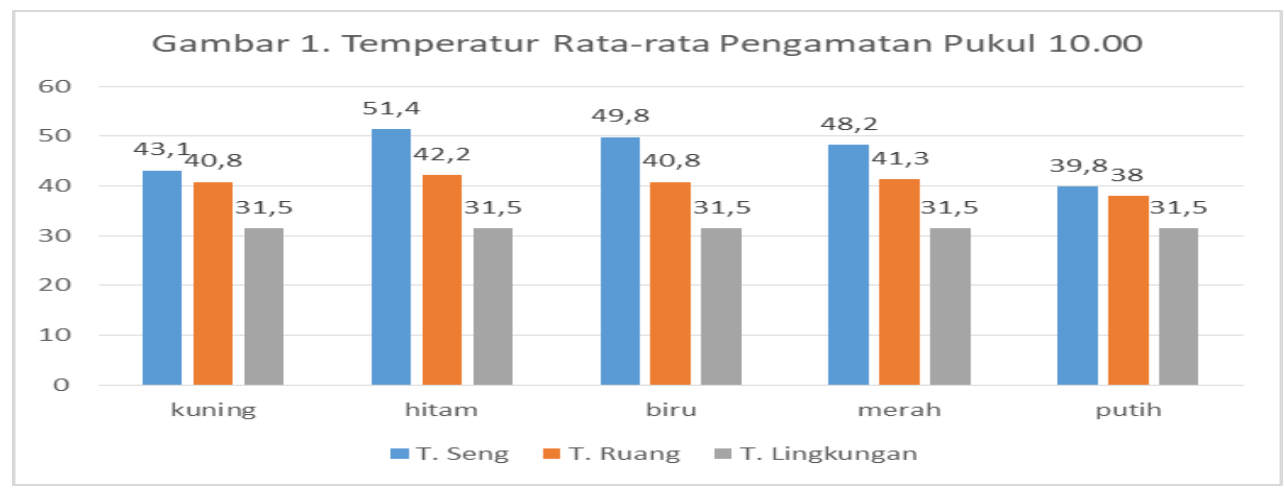

Gambar 2. Temperatur Rata-Rata Pengamatan Pukul 10.00

Hasil pengamatan pada Pukul 10.00 menunjukkan bahwa temperature lingkungan sebesar 31,5 Celcius. Pada saat ini, temperatur seng dan temperature ruang tertinggi terdapat pada seng yang berwarna hitam. Sementara itu, suhu seng dan suhu ruang terendah berada pada seng yang berwarna putih. Pada Pukul 10.00 semua temperatur ruang pada seluruh warna seng berada di bawah temperature seng.

Pengamatan Pukul 11.00 memberikan hasil bahwa mulai terjadi peningkatan temperature ruang pada semua warna seng. Temperature seng dan temperature ruang tertinggi masih berada pada seng berwarna hitam. Sementara temperature seng dan ruang terendah juga masih berada pada seng berwarna putih.

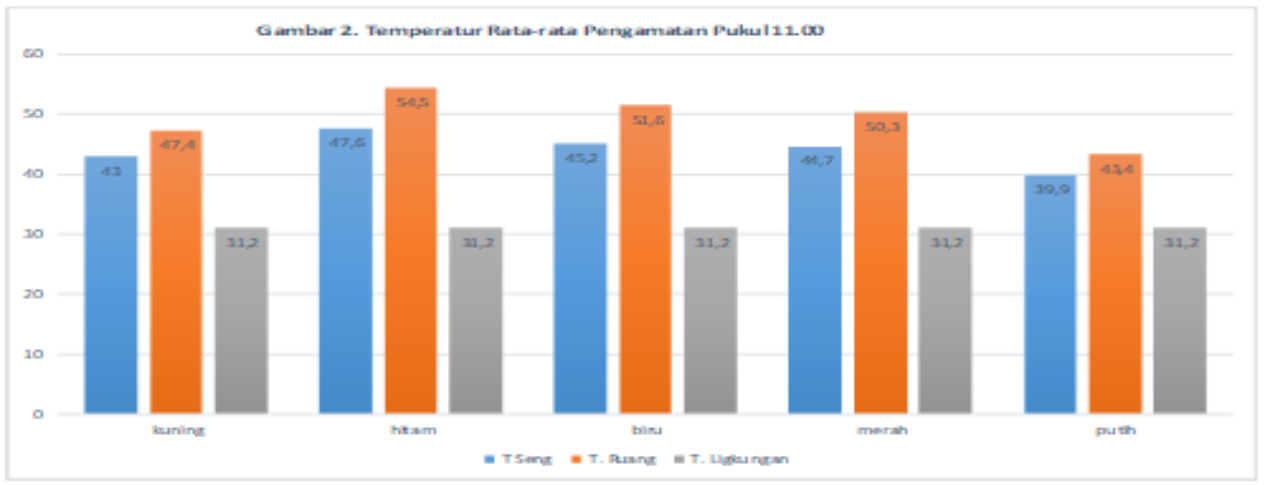

Gambar 3. Temperatur Rata-Rata Pengamatan Pukul 11.00

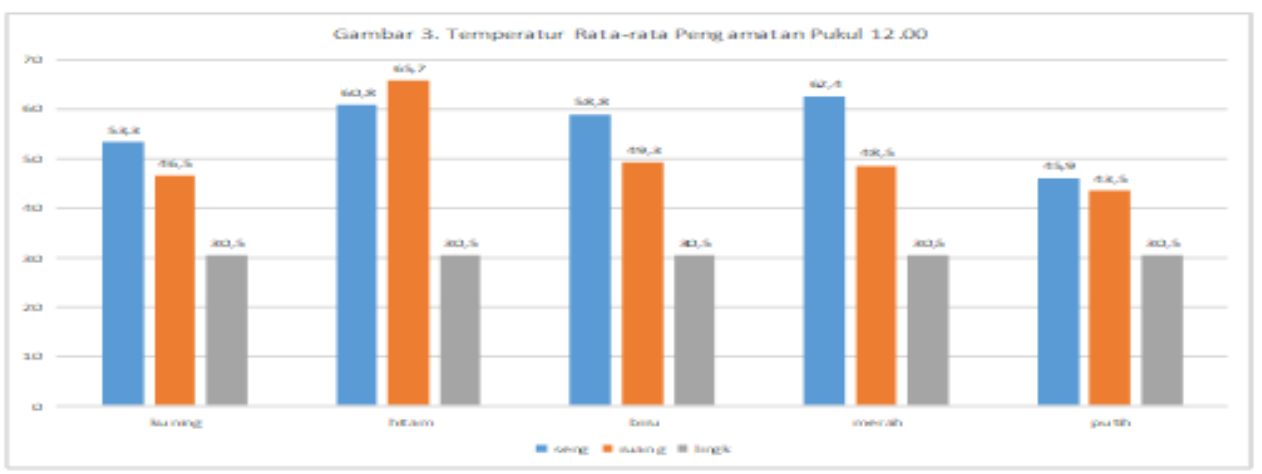

Gambar 4. Temperatur Rata-Rata Pengamatan Pukul 12.00 
Pada Pukul 12.00 pengamatan menunjukkan hasil yang berbeda dengan 2 pengamatan sebelumnya. Temperatur seng tertinggi berada pada seng berwarna merah sementara temperature ruang tertinggi berada pada seng berwarna hitam. Semua temperature ruang pada seng selain hitam menunjukkan temperature ruang yang lebih rendah daripada temperature seng. Sementara pada seng berwarna hitam temperature ruang lebih tinggi daripada temperature seng. Temperature terendah baik pada ruang maupun pada seng berada pada seng yang berwarna putih.

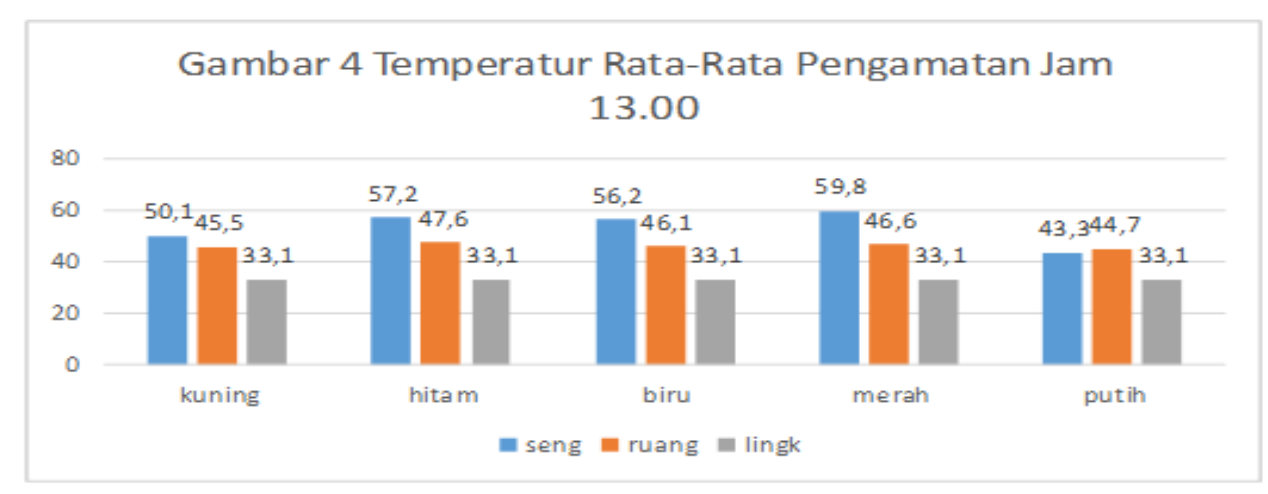

Gambar 5. Temperatur Rata-Rata Pengamatan Pukul 13.00

Pada Pukul 13.00 pengamatan menunjukkan hasil temperatur ruang tertinggi pada seng warna hitam sementara temperature seng tertinggi pada seng warna merah. Semua temperature ruang pada seng menunjukkan temperature seng yang lebih tinggi daripada temperature ruang. Sementara pada seng berwarna merah temperature seng lebih tinggi daripada temperature ruang. Temperature terendah baik pada ruang maupun pada seng berada pada seng yang berwarna putih.

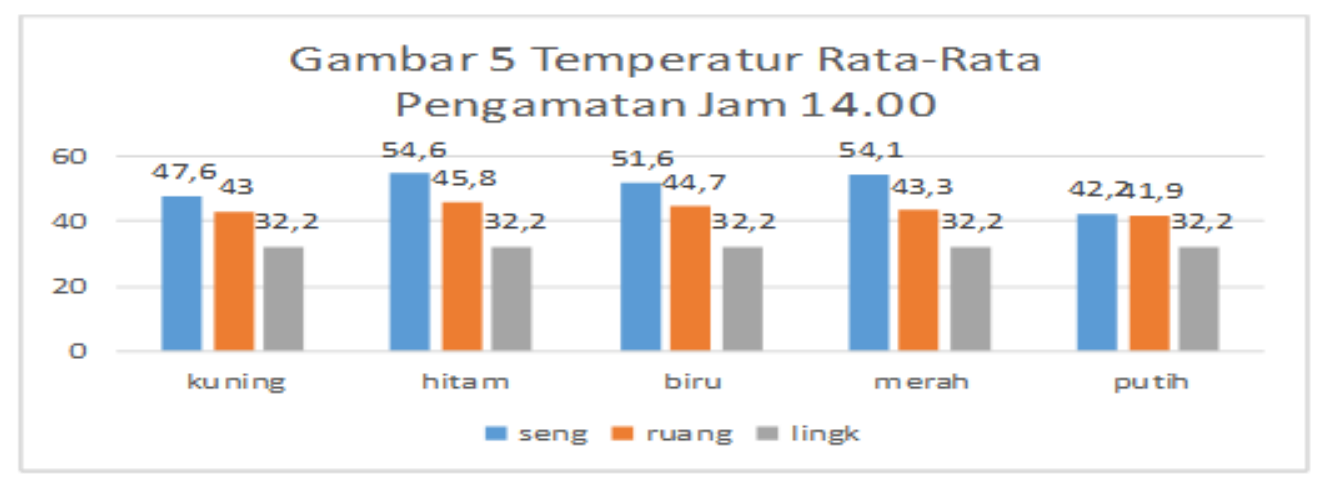

Gambar 6. Temperatur Rata-Rata Pengamatan Pukul 14.00

Pada Pukul 14.00 pengamatan menunjukkan hasil temperatur seng tertinggi pada seng warna hitam dan juga temperature ruang tertinggi pada seng warna hitam. Semua temperature ruang pada seng menunjukkan temperature seng yang lebih tinggi daripada temperature ruang. Sementara pada seng berwarna hitam temperature seng lebih tinggi daripada temperature ruang. Temperature terendah baik pada pada ruang maupun pada seng berada pada seng yang berwarna putih. 


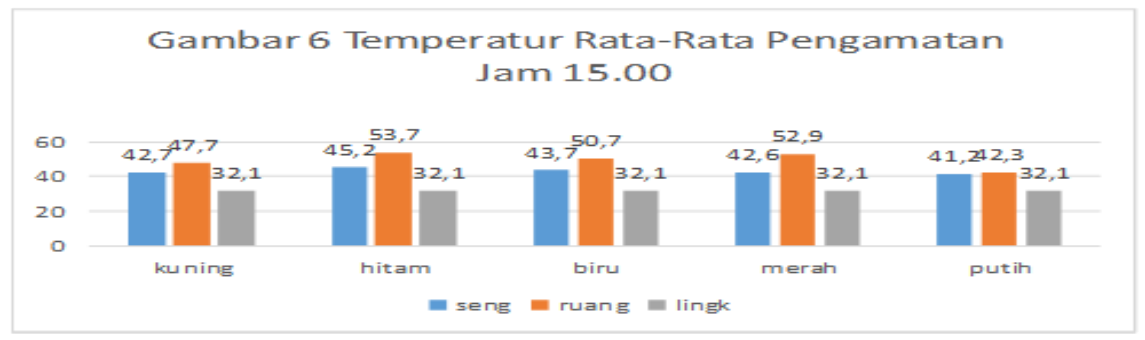

Gambar 7. Temperatur rata-rata Pengamatan Pukul 15.00

Pada Pukul 15.00 pengamatan menunjukkan hasil temperature ruang tertinggi pada seng warna hitam dan juga temperature seng tertinggi pada seng warna hitam. Semua temperature ruang pada seng menunjukkan temperature ruang yang lebih tinggi daripada temperature seng. Sementara pada seng berwarna hitam temperature ruang lebih tinggi daripada temperature seng. Temperature terendah baik pada ruang maupun pada seng berada pada seng yang berwarna putih.

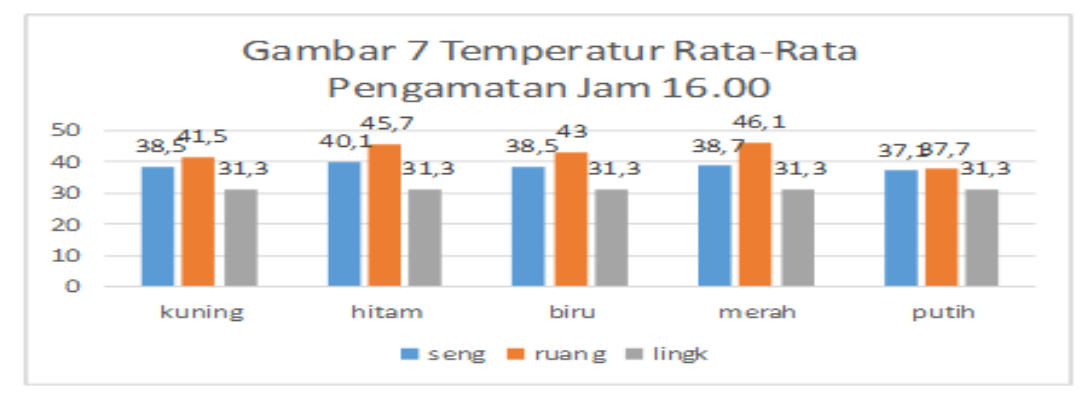

Gambar 8. Temperatur rata-rata Pengamatan Pukul 16.00

Pada Pukul 16.00 pengamatan menunjukkan hasil temperatur ruang tertinggi pada seng warna merah sementara temperature seng tertinggi pada seng warna biru. Semua temperature ruang pada seng menunjukkan temperature ruang yang lebih tinggi daripada temperature seng. Sementara pada seng berwarna merah temperature ruang lebih tinggi daripada temperature seng. Temperature terendah baik pada pada ruang maupun pada seng berada pada seng yang berwarna putih.

Gambar 8 memperlihatkan distribusi temperatur di dalam ruangan berdasarkan perbedaan warna atap seng.

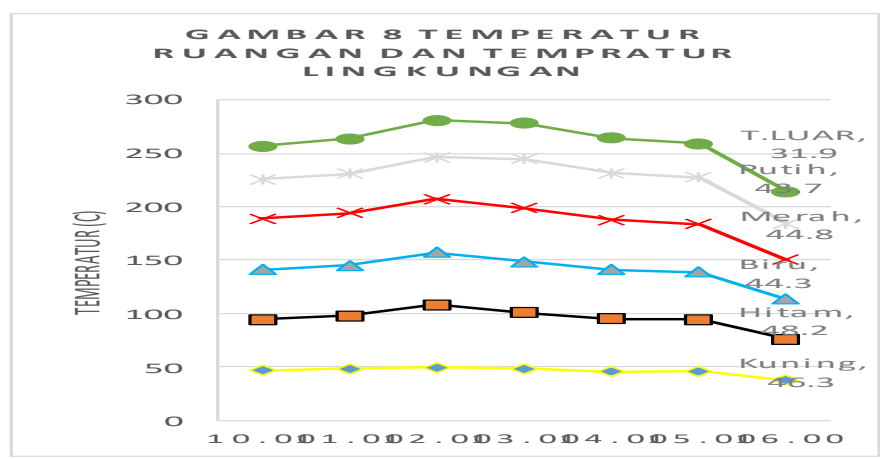

Gambar 9. Temperatur Ruangan dan Temperatur Lingkungan 
Temperatur ruang tertinggi dari seng berlapis warna hitam $49,2{ }^{\circ} \mathrm{C}$, dan yang terendah pada warna putih 40,9, dari pengamatan suhu lingkungan terdapat temperatur paling tinggi pada jam 12.00. temperature ruangan terjadi peningkatan temperature tertinggi pada pukul 12.00 pada seng berwarna hitam. Ditribusi termperatur ruangan dapat dirata-ratakn yang warna kuning $46,0{ }^{\circ} \mathrm{C}$, warna hitam $49,2{ }^{\circ} \mathrm{C}$, , warna biru $45,5^{\circ} \mathrm{C}$ dan seng warna putih 40,9 ${ }^{\circ} \mathrm{C}$.

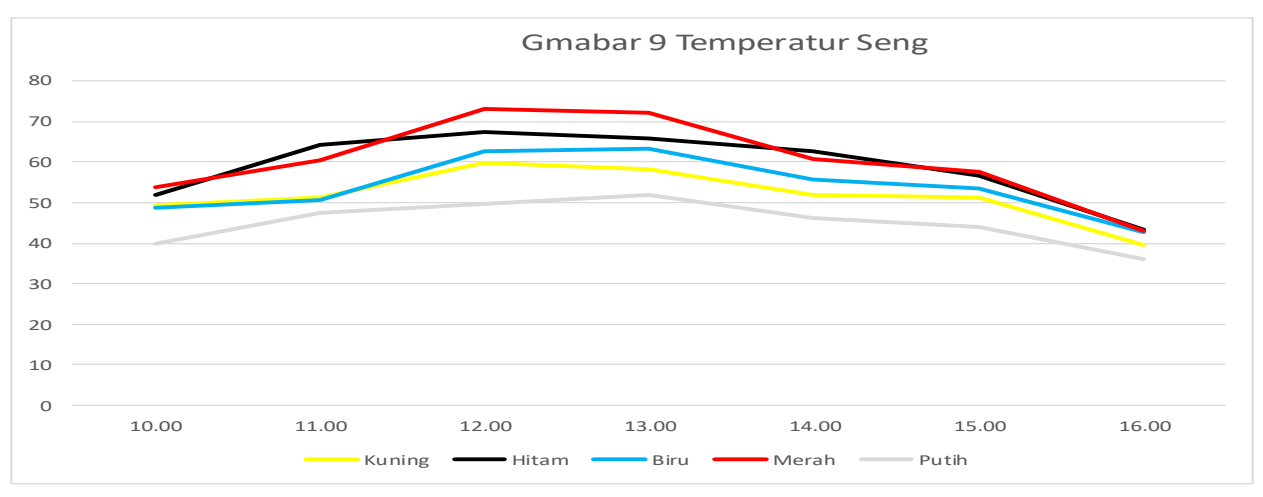

Gambar 10. Temperatur Seng

Temperatur seng tertinggi pada seng warna merah $60,0{ }^{\circ} \mathrm{C}$, dan yang terendah pada warna putih 45,0 dan temperature seng tertinggi pada pukul 12.00. terdapat temperatur paling rendah pada pukul 16.00 pada seng warna putih. Maka dapat hitung panas yang diserapa sebagai berikut.

Dimana:

$$
\mathrm{Q}=\mathrm{m} \cdot \mathrm{Cp} \cdot \Delta \mathrm{T}
$$

$\mathrm{Q} \quad=$ Panas yang diserap (Joule)

$\mathrm{M} \quad$ = Massa Udara Dalam Ruangan $(\mathrm{kg})$

$\mathrm{Cp}=$ Spesifik Heat Udara $(\mathrm{J} / \mathrm{kg} . \mathrm{K})$

$\Delta \mathrm{T}=$ Beda Temperaturdalam dan Luar Ruangan $(\mathrm{K})$

$\mathrm{Q} \quad=\mathrm{m} . \mathrm{Cp} \cdot \Delta \mathrm{T}$

$\mathrm{Q}=53,8 \times 27,5 \times 32,4$

$\mathrm{Q}=47,9$ (Joule)

Dari perhitungan didapat yang mana panas yang diserap didalam ruangan sebesar 47,9 joule, maka dari rata keseluruan pengujian dapat digambarkan temperature yang diserap dengan temperature ruangan dan temperature seng, ada perbedan yaitu temperature ruang sebesar 45,6 dan temperature seng 53,8, dari perbedaan antara temperature ruang dan seng dapat di dijelaskan yang mana temperatut ruang pada jam 12.00 wib dan temperature seng tertinggi pada pukul 13.00 .

Berdasarkan jabaran hasil penelitian tersebut dapat dikatakan bahwa setiap warna pelapis seng mempunyai kemampuan menyerap panas yang berbeda. Warna yang berbeda akan mempengaruhi daya serap terhadap intensitas cahaya dan panas yang berbeda (Ilminnafik et al., 2015). Dimana warna yang terang akan memiliki daya serap yang lebih rendah sedangkan warna yang gelap akan mempunyai daya serap yang lebih besar, hal ini karena pengaruhi oleh perbedaan cahaya dalam bentuk gelombang elektromagnetik yang di serap dan di pantulkan oleh masing-masing warna (Abdul et al., 2019; Ali, 2010). Setiap warna cahaya memiliki panjang gelombang yang berbeda, serta memiliki kemampuan 
penetrasi dan daya serap yang berbeda (Rahayu et al., 2011). Apabila diurutkan berdasarkan kmampuan penyerapan panas matahari mulai yang dari tetinggi sampai dengan yang terendah adalah atap seng warna hitam, merah, biru, kuning, dan putih. Seng yang berwarna Hitam mempunyai daya serap panas yang besar. Hal ini karena Warna hitam memiliki perubahan suhu yang ekstrem karena dapat menyerap sebagian besar panas dalam waktu singkat, dan sama halnya, juga dapat melepaskan sebagian besar panas dalam waktu singkat.

\section{Conclusion}

Penelitian ini menyimpulkan bahwa atap seng yang menyerap panas matahari tertinggi adalah atap seng yang berwarna hitam. Sementara itu, atap seng yang berwarna putih adalah atap seng yang penyerapan matahari terendah. Apabila diurutkan berdasarkan kmampuan penyerapan panas matahari mulai yang dari tetinggi sampai dengan yang terendah adalah atap seng warna hitam, merah, biru, kuning, dan putih.

\section{References}

Abdul, A. H., Rimbawati, Rifqi Fathullah Qayyim, \& Faisal Lubis. (2019). Analisa Penurunan Tingkat Penurunan Iluminasi Sistem Penerangan Terhadap Lifetime Lampu. RELE (Rekayasa Elektrikal Dan Energi) : Jurnal Teknik Elektro, 1(2), 93100. https://doi.org/10.30596/rele.v1i2.3015

Ali, S. G. (2010). Adaptasi Suhu Tubuh Terhadap Latihan Dan Efek Cedera Di Cuaca Panas Dan Dingin. Jorpres, 6(2), 123-134.

Cahyono, W. E. (2015). Pengaruh Pemanasan Global Terhadap Lingkungan Bumi. Berita Dirgantara LAPAN, $16, \quad 28-31$. http://jurnal.lapan.go.id/index.php/berita_dirgantara/article/download/732/649

Fajar, D. M., \& Rohmah, I. G. (2019). Kajian Eksperimen Pengukuran Suhu Matahari Menggunakan Peralatan Sederhana Sebagai Pengayaan Materi Radiasi di Tingkat SMA. Indonesian Journal Of Mathematics and Natural Science Education, 1(1), 918. https://mass.iain-jember.ac.id/index.php/mass/article/view/7/6

Idayati, R. (2007). Pengaruh Pemanasan Global ( Global Warming) Terhadap Lingkungan Dan Kesehatan. Jurnal Kedokteran Syiah Kuala, 7(1), 43-48.

Iek, Y., Sangkertadi, \& Moniaga, I. L. (2014). Kepadatan Bangunan Dan Karakteristik Iklim Mikro Kecamatan Wenang Kota Manado. Sabua, 6(3), 286-292.

Ilminnafik, N., L.S, D., Sutjahjono, Hary, M, A. A. M. M., \& Erfani. (2015). Variasi bahan dan warna atap bangunan untuk Menurunkan Temperatur Ruangan akibat Pemanasan Global. Proceeding Seminar Nasional Tahunan Teknik Mesin, XIV (SNTTM.

Kaamin, M., Rahman, R. A., Suwandi, A. K., Kesot, M. J., \& Razzaq, A. R. A. (2013). Kajian alternatif mengurangkan suhu rumah beratap zink di waktu tengahari. Proceeding of the International Conference on Social Science Research, ICSSR 2013. 4-5 June 2013, Penang, Malaysia, June, 357-368.

Machzumy. (2018). KRITERIA IDEAL LOKASI RUKYAT (Studi Analisis Observatorium Tgk. Chiek Kutakarang). JurnalAt-Tafkir, XI(2).

Rahayu, K. R., Bustaman, H., \& Arief, M. (2011). Pengaruh Perbedaan Warna Cahaya terhadap Pertumbuham Kultur. Jurnal Ilmiah Perikanan Dan Kelautan, 3(2), 111127. https://e-journal.unair.ac.id/JIPK/article/download/11605/6616

Sarkawi, D. (2011). Pengaruh Pemanasan Global Terhadap Perubahan Iklim. In Cakrawala Jurnal Humaniora (Vol. 11, Issue 2, pp. 128-137). http://ejournal.bsi.ac.id/ejurnal/index.php/cakrawala/article/view/3552

Vivi Triana. (2008). Pemanasan Global 3. Utusan Malaysia, September, 36. 